\title{
Sequential Monitoring of Pre-exposure Antirabies Vaccinal Neutralizing Antibodies in Dogs
}

\author{
B.T. Nethravathi, P.T. Ramesh, R.E. Sushma
}

10.18805/IJAR.B-4767

\begin{abstract}
Background: Effective animal vaccines against Rabies that provide a considerable duration of immunity and mass parenteral vaccination programmes remain the mainstay of canine rabies control. Animal birth control $(A B C)$ programmes coupled with pre-exposure antirabies vaccination with booster dose at regular interval have been advocated as a method to control urban street male and female dog populations and ultimately human rabies in Asia. The present study is aimed to determine the persistence of antirabies neutralizing antibodies to pre-exposure vaccination in dogs and the effect of booster vaccination on pre-exposure antirabies vaccinal neutralizing antibody levels.

Methods: The study was conducted in 30 non-descript dogs which were divided into two groups containing 15 animals each. Dogs in group I were given pre exposure prophylaxis with booster dose after 21 days and animals in group II were given primary vaccination without any booster dose. Serum samples were collected at $0^{\text {th }}, 7^{\text {th }}, 14^{\text {th }}, 21^{\text {st }}, 28^{\text {th }}, 60^{\text {th }}, 90^{\text {th }}$ and $120^{\text {th }}$ days post vaccination. Seromonitoring of antirabies vaccinal antibodies was done in both groups by RFFIT.

Result: 80 per cent of the animals in group I were able to maintain the mean antibody titre above protective level upto 4 months successfully, whereas, 40 per cent of the animals in group II were able to maintain mean antibody titer above protective level only upto 2 months. With the inactivated vaccine, booster dose given three weeks after the primary vaccination has ensured levels of neutralizing antibodies $>0.5 \mathrm{IU} / \mathrm{ml}$ for a period of at least four months.
\end{abstract}

Key words: Antibody titre, Neutralizing antibodies, Neutralizing antibody, RFFIT, Seromonitering.

\section{INTRODUCTION}

Rabies is one of the ancient diseases which continues to affect countless human and animal populations on a global basis. It is one of the most feared/deadly zoonotic diseases with an almost invariably fatal encephalomyelitis (Dietzschold et al., 1996) caused by a RNA virus belonging to the genus Lyssavirus of the family Rhabdoviridae. Rabies Virus (RABV) possesses a single-stranded, linear, non-segmented, negativesense RNA approximately $12 \mathrm{~kb}$ in size (Tordo et al., 1986). It emerges as a significant infection with serious impact on public health both in rabies-free and rabies endemic countries.

India is a vast country with rabies as an important zoonotic disease with dogs as main reservoirs. The control of rabies in animal reservoirs depend on control of rabies in dogs. Since canines are the principal reservoirs of rabies in the urban areas, varieties of vaccines have been developed to prevent rabies infection in dogs (Meslin et al., 1997). The antibody titres are determined by using Rapid fluorescent focus inhibition test which is recommended by WHO as a standard test to determine rabies virus neutralizing antibody titre (WHO, 1992). The Rapid Flourescent Focus Inhibition Test (RFFIT) involves neutralizing a constant dose of virus by antibodies present in the serum to be assayed and the extent of neutralization will be detected by inoculating in cell culture and then presence or absence of viral antigen by direct fluorescent antibody (DFA).

\section{MATERIALS AND METHODS}

The present study was carried out to determine the persistence of antirabies neutralizing antibodies to pre
Department of Veterinary Medicine, Veterinary College, Bengaluru560 001, Karnataka, India.

Corresponding Author: R.E. Sushma, Department of Veterinary Medicine, Veterinary College, Bengaluru-560 001, Karnataka, India. Email: drsushmavet@gmail.com

How to cite this article: Nethravathi, B.T., Ramesh, P.T. and Sushma, R.E. (2022). Sequential Monitoring of Pre-exposure Antirabies Vaccinal Neutralizing Antibodies in Dogs. Indian Journal of Animal Research. DOI: 10.18805/IJAR.B-4767.

Submitted: 02-09-2021 Accepted: 14-01-2022 Online: 04-03-2022

exposure anti-rabies vaccination in dogs and to study the effect of booster vaccination on pre exposure anti-rabies vaccinal neutralizing antibody levels. The research was carried out at OIE Twinned KVAFSU-CVA-CRUCELL Rabies Diagnostic Laboratory, Department of Microbiology, Veterinary College, Hebbal, Bengaluru during the year 2018. Dogs maintained in Karuna Animal Shelter, Bengaluru with good health status and with unknown history of anti-rabies vaccination were selected for the study. They were divided into two equal groups of 15 animals each. "Rabisin $®$ " (MERIAL) anti-rabies vaccine was used in this study for vaccinating the animals at the dose of $1 \mathrm{ml}$ intramuscular at thigh region per animal which contained inactivated rabies virus with a potency $\geq 2.5 \mathrm{IU} /$ dose.

Animals in Group I were administered with anti-rabies vaccine with one booster dose of vaccination after 21 days and animals in Group II were administered with anti-rabies 
vaccine without booster dose of vaccination. Two mililiters of blood was collected with sterile precautions and serum was separated and stored at $-20^{\circ} \mathrm{C}$ until further study. The blood samples were collected on $0,7,14,28,60,90$ and 120 days post vaccination. Seromonitoring of antirabies vaccinal antibodies was done in both groups by RFFIT for which the rabies virus strain PV 3462 (Dr. Larghi's strain) and BHK 21 cells maintained in the OIE Twinned KVAFSU-CVA-CRUCELL Rabies Diagnostic Laboratory, Department of Microbiology, Veterinary College, Hebbal, Bengaluru was used.

\section{RESULTS AND DISCUSSION}

Rabies is a viral, zoonotic and fatal disease, causing encephalomyelitis in human and animals and is considered to be a re-emerging zoonosis in many parts of the world (Rupprecht et al., 2002). Animals and human beings usually acquire infection following a bite by a rabid animal (Hemachudha et al., 2002). The annual number of human deaths caused by rabies is estimated to be 55,000 worldwide (Knobel et al., 2005), about 32,000 in Asia (Sugiyama and Ito, 2007). Three principal global areas of rabies have been defined. These areas are (a) countries with enzootic canine rabies (all of Asia, Latin America and Africa), (b) countries in which canine rabies has been brought under control and wildlife rabies predominates (Western Europe, Canada and the United States), (c) rabies-free countries (mostly islands, including England, Australia and Japan) (De Serres et al., 2008). Rabies occurs mainly in urban areas, in which stray dogs play an important role as a reservoir and transmitter of the disease to humans and domestic animals (Ramanna et al., 1991; Bhatia et al., 2004 and Nagarajan et al., 2006). In India, more than 95 per cent of the animal bites in humans are caused by dogs. Even rabid stray cattle have also been found to potentially transmit rabies to humans when ecological and societal factors are favourable (Nagarajan et al., 2006). It is presumed that domestic animals and rarely, human beings residing in villages along the forest areas are the common victims of wild animal bites and eventual contributors to the spread of rabies. Rabies in livestock caused considerable losses to Indian livestock industry, although a precise estimate is not available (Knobel et al., 2005). Currently, the stray dogs are being regularly vaccinated through the $A B C$ programmes initiated by the State governments. With the international movement of animals being so frequent in recent years, it has become mandatory to ensure that the dogs have protective levels of neutralizing antibodies to Rabies virus before they are transported to some of the countries (WHO, 2013). At present, assessing the level of vaccinal antibodies is being accomplished through RFFIT and FAVN. Except in adult dogs with a past immunisation history, a single dose of anti-rabies vaccine is unable to maintain a good protective antibody titre until one year in 50 per cent of adult dogs without previous immunisation and in puppies from immunised and nonimmunised bitches (Gunatilake et al., 2003).
In Group I, the animals were vaccinated for pre exposure prophylaxis with the booster dose of vaccination on day 21 . The mean antibody titer against rabies on day 0 was $<0.5 \mathrm{IU} / \mathrm{ml}$. as the similar observations were made by Albas et al. (1998), where the animals used in their experiment were not found with detectable rabies antibody titres at day 0 , indicating that they were probably not vaccinated previously.

The protective level against rabies based on mean antibody titre on day 7 , was 93.33 per cent in study population and there was a significant $(p<0.05)$ increase in the mean antibody titer from day 0 to day 7 indicating that neutralizing antibodies were produced against rabies viral antigen after the vaccination. Brinkman (2003) studied immune characteristics of both humoral and cellular immune responses after rabies vaccination in 17 human healthy patients, where results using ELISA test indicated that 7 days after primary vaccination there was a significant rise in level of $\lg \mathrm{M}$.

On day 14 , the mean antibody titre reached the peak i.e., $9.867 \mathrm{IU} / \mathrm{ml}$ with 100 per cent of protection. Briggs et al. (2000) recorded 96.66 per cent of animals showed antibody titre $>0.5 \mathrm{IU} / \mathrm{ml}$ on day 14 of post vaccination and Lavender (1973) observed peak antibody titer on $14^{\text {th }}$ day of post vaccination in monkeys.

On $21^{\text {st }}$ day, the mean antibody titre indicated protection level of 93.33 per cent in study animals which is much higher than that observed by Nelson (2006) where the animals which received recombinant DNA vaccine showed 50 per cent protection. This variation could be due to difference in type of vaccine which is related to expression of plasmids in recombinant vaccine. A significant increase in the antibody titer was observed from $21^{\text {st }}$ day to $28^{\text {th }}$ day where Fodor et al. (2000) and Brinkman (2003) reported that one week after the booster vaccination (28 ${ }^{\text {th }}$ day) the level of $\lg G$ increased significantly faster in study population.

On $60^{\text {th }}$ day, the mean antibody titre indicated 100 per cent protection. Where Nelson (2006) recorded protection level of 40 per cent in animals received inactivated rabies vaccine with booster dose given after 21 days of primary vaccination and also stated that difference in antibody titer could be due to variation in strain of virus, the cell line in which it was grown, adjuvants used in their preperation, age, sex and nutritional status of the animals under study.

On day 90 and day 120, 86.66 per cent and 80 per cent protection was observed, respectively. there was no significant decrease in the mean antibody titre between day 90 and day 120 , but there was persistent decline in the values observed after day 60 , which is in accordance with Da Silva et al. (2000) who observed the titer of rabies neutralizing antibody in the serum samples from bovines immunized with the 2 dose (one month interval) of $2 \mathrm{ml}$ of IPVvac (rabies vaccine prepared with the PV fixed virus grown on BHK-21 cell-line, inactivated by $\beta$ propiolactone, adjuvanted with aluminium hydroxide). 
In Group II, the dogs were vaccinated for pre exposure prophylaxis without the booster dose of vaccination. The mean antibody titer against rabies on day 0 was $<0.5 \mathrm{IU} / \mathrm{ml}$.

On day 7,13 out of 15 dogs ( $86.66 \%$ ) were seroconverted with antibody titre $>0.5 \mathrm{IU} / \mathrm{ml}$. The seroconversion rate rose to 100 per cent $(15 / 15)$ on day 14 . There was a significant $(p<0.05)$ increase in the mean antibody titer from day 0 to 7 and day 7 to 14 . Briggs et al. (2000) also recorded 96.66 per cent of animals showing antibody titre $>0.5 \mathrm{IU} / \mathrm{ml}$ on day 14 of post vaccination.

The seroconversion rate declined to 93.33 per cent $(14 / 15)$ on day 21 and further dropped to 86.66 per cent $(13 / 15)$ on day 28 and 66.66 per cent $(10 / 15)$ on day 60 and 53.33 per cent $(8 / 15)$ on day 90 and 40 per cent $(6 / 15)$ on day 120 . There was a significant $(p<0.05)$ decrease in mean antibody titer from day 14 to 21 . Further, there was no significant difference in mean of the titer between 21 and 28, 28 and 60,60 and 90,90 and 120 days indicating the persistent decrease in the per cent of protection against rabies among the animals from day 21 .

Geometric mean titers were 1.07, 10.57, 2.83, 2.07, $0.57,0.40$ and $0.33 \mathrm{IU} / \mathrm{ml}$ on $7,14,21,28,60,90$ and 120 days, respectively. From day 90 , the mean antibody titer was $<0.5 \mathrm{lU} / \mathrm{ml}$ which was below protective level against rabies. So vaccination of animals without booster dose maintains the antibody titre above protective level upto only day 60 post vaccination, after which there will be no detectable neutralizing antibodies against rabies antigen in the serum. Tepsumethanon et al. (1991) observed the mean antibody titer of $2.14,2.30,0.45$ and $0.14 \mathrm{IU} / \mathrm{ml}$ on 14,30 , 60 and 180 days, respectively and the mean antibody titer was $<0.5 \mathrm{IU} / \mathrm{ml}$, which is below protective level, after day 60 post vaccination in the animals under study.

Similarly, Sami et al. (2016) has reported that from two months after the primary vaccination, the humoral response becomes significantly weaker and decreases regularly to reach an average rabies antibody titer of $0.57 \mathrm{IU} / \mathrm{ml}, 4$ month post vaccination. Oliveira et al. (2000) also observed that single dose of any of the tested vaccines did not induce detectable levels of antibodies in the majority of animals after the first vaccination.

Various factors may influence the level of titer in vaccinated dogs such as timing of serum collection after vaccination, age (Hogen Esch et al., 2004, Mansfield et al., 2004), breed (Berndtsson et al., 2011), management (Yale et al., 2014), gender (Mansfield et al., 2004 and Kennedy et al., 2007), genetic (Kennedy et al., 2007), nutritional status (Manickama et al., 2008), stress (Van loveren et al., 2001), effect of endoparasitism (Mojzisova et al., 2007), effect of multiple vaccinations (Green, 2012), body size (Green, 2012). The response to vaccination varied between the individuals within the Group which could be attributed to genetic and host factors (Albus et al., 2006). A further conceivable explanation is that the use of virus strains (PV 3462) for antibody titration may be different from those found in the vaccines (PV Strain of fixed rabies virus adopted to BHK 21 clone 13 cells), thus responsible for conflicting results.

\section{CONCLUSION}

There was no significant $(p>0.05)$ difference in mean antibody titer between $0,7,14$ and 21 day post vaccination in Group I and Group II. But there was significant $(p<0.05)$ difference in mean antibody titer between 28,60, 90 and 120 days post vaccination in Group I and Group II. This signifies the importance of seromonitoring of immune status of dogs with reference to neutralizing antibodies as a measure of animal health surveillance and also timely advice for necessary booster dose for the dogs. In the present study, 80 per cent of the animals in Group I which were given booster dose after 21 days post vaccination, were able to maintain the mean anitibody titre above protective level upto 4 months successfully whereas, 40 per cent of the animals in Group II which were given primary vaccination without booster dose, were able to maintain mean antibody titer above protective level only upto 2 months. So the animals with best titer were those given a booster of inactivated vaccine after three weeks. It is concluded that only one dose of tissue culture vaccine in previously unvaccinated dogs by intramuscular route of injection is not adequate to maintain rabies neutralizing antibodies above protective level for 4 months of the study period. With the inactivated vaccine used in this study, booster dose given three weeks after the primary vaccination has ensured levels of neutralizing antibodies $>0.5 \mathrm{IU} / \mathrm{ml}$ for a period of at least four months of study period.

\section{REFERENCES}

Albas, A., Fontolan, O.L., Pardo, P.E., Bremer, N.H. and Sartori, A. (2006). Interval between first dose and booster affected antibody production in cattle vaccinated against rabies. J. of Venom. Anim and Toxins Trop Dis. 12(3): 476-486.

Albas, A., Pardo, P.E., Gomes, A.B., Bernardi, F. and Ito, F.H. (1998). Effect of a booster-dose of rabies vaccine on the duration of virus neutralizing antibody titer in bovines. Revista da Sociedade Brasileira de Medicina Tropical. 31(4): 367-371.

Albas, A., Picolo, M.R., Soares, C.N., Bachega, H.V.U. and Tarumoto, M.H. (2013). Humoral immune response in dogs and cats vaccinated against rabies in southeastern Brazil. J. of Venom. Anim. and Toxins Trop Dis. 19: 19-17.

Berndtsson, L.T., Nyman, A.J., Rivera, E. and Klingeborn, B. (2011). Factors associated with the success of rabies vaccination of dogs in Sweden. Acta Vet. Scand. 53: 22-28.

Bhatia, R., Ichhpujani, R.L., Madhusudana, S.N. and Hemachudha, T. (2004). Rabies in South and Southeast Asia. In. Program and Abstracts of the WHO Expert Consultation on Rabies, Geneva, Switzerland.

Briggs, D.J., Banzhoff, A., Nicolay, U., Sirikwin, S., Dumavibhat, B., Tongswas, S. and Wasi, C. (2000). Antibody response of patients after post exposure Rabies vaccination with small intradermal dose of purified chick embryo cell vaccine or purified vero cell Rabies vaccine. Bull. World health Organization. 78: 693-698.

Brinkman, D.M. (2003). Vaccination with rabies to study the humoral and cellular immune response to a T-cell dependent neoantigen in man. J. Clin. Immunol. 23: 528-538. 
Da silva, A.C.R., Caporale, G.M.M., GonçalveS, C.A., Targueta, M.C., Comin, F., Zanetti, C.R. and Kotait, I. (2000). Antibody response in cattle after vaccination with inactivated and attenuated rabies vaccines. J. São Paul. Inst. Trop. Med. 42(2): 95-98.

De, Serres. G., Dallaire, F. and Cote, M. (2008). Bat rabies in the United States and Canada from 1950 through 2007: human cases with and without bat contact. Clin. Infect. Dis. 46: 1329-1337.

Dietzschold, B., Rupprecht, C.E., Fu, Z.F. and Koprowski, H. (1996). Rhabdoviruses. In. Field's Virology. [Edt. Fields, B., Knipe, D., Howley, P.M., Chanock, R.M., Melwick, J.L., Monath, T.P. and Roizman, B., Edn]. $3^{\text {rd }}$., Lippincott-Raven Press, Philadelphia, USA. pp 1137-1159.

Fodor, I., Kucsera, L., Fodor, N., Palfi, V. and Grabko, V.I. (2000). Gene immunization of mice with plasmid DNA expressing Rabies virus glycoprotein. Acta. Vet. Hung. 48: 229-236.

Green, C.E. (2012). Rabies and other Lyssavirus Infections. In. Infectious Diseases of the Dog and Cat. Edn. $4^{\text {th }}$., Saunders Elsevier. 179-197.

Gunathilake, M., Wimalaratne, O. and Perera, K.A.D.N. (2003). Persistence of antibody titres in adult dogs and puppies following anti-rabies imminization. Ceylon. J. of Med. Sci. 46: $67-71$.

Hemachudha, T., Laothamatas, J. and Rupprecht, C.E. (2002). Human rabies: A disease of complex neuropathogenetic mechanisms and diagnostic challenges. Lancet. Neurol. 1: 101-109.

Hogenesch, H., Thompson, S., Dunham, A., Ceddia, M. and Hayek, M. (2004). Effect of age on immune parameters and the immune response of dogs to vaccines: A cross-sectional study. Vet. Immunol. Immunopathol. 97(1): 77-85.

Kennedy, L.J., Lunt, M., Barnes, A., Mcelhinney, L., Fooks, A.R., Baxter, D.N. and Olliera, W.E.R. (2007). Factors influencing the antibody response of dogs vaccinated against rabies. Vaccine. 25: 8500-8507.

KnobeL, D.L., Cleaveland, S., Coleman, P.G., Fevre, E.M., Meltzer, M.I. and Miranda, M.E. (2005). Re-evaluating the burden of rabies in Africa and Asia. Bull World Health Organisation. 83: 360-368.

Lavender, J.F. (1973). Immune response in primates with duck cell culture vaccine. J. Appl. Microbiol. 25: 327-331.

Manickam, R., Basheer, M.D. and Jayakumar, R. (2008). Postexposure prophylaxis (PEP) of rabies infected Indian street dogs. Vaccine. 26(51): 6564-6568.

Mansfield, K.L., Burr, R.D., Snodgrass, D.R., Sayers, R. and Fooks, A.R. (2004). Factors affecting the serological response of dogs and cats to rabies vaccination. Vet. Rec. 154: 423-426.

Meslin, F.X., Fishbein, D.B. and Matter, H.C. (1997). Rationale and prospects for rabies elimination in developing countries. Curr. Top. Microbiol. Immunol. 187: 1-26.
Mojzisova, J., J, Suli., M., Goldova., V., Bajova. and Svrcek. (2007). The effect of endoparasitism on the immune response to antirabies vaccination in puppies. Acta Parasitol. 52(2): 176-180.

Nagarajan, T., Mohanasubramanian, B., Seshagiri, E.V., Nagendrakumar, S.B., Saseendranath, M.R. and Satyanarayana, M.L. (2006). Molecular epidemiology of rabies virus isolates in Indian J. Clin. Microbiol. 44: 3218-3224.

Nelson, M.M. (2006). Studies on recombinant DNA vaccine against rabies in dogs. M.V.Sc. Thesis, Karnataka Veterinary, Animal and Fisheries Sciences University, Bidar, Karnataka.

Oliveira, A.N.D. andrade, M.C.R., Silva, M.V.D., Moura, W.C.D. and Cortez Contreiras, E. (2000). Immune response in cattle vaccinated against rabies. Mem. Inst. Oswaldo. Cruz. 95: 83-88.

Ramanna, B.A. and Srinivasan, V.A. (1992). Serological response in cattle to tissue culture vaccine. Indian Vet. J. 69: 8-10.

Rupprecht, C.E., Hanlon, C.A. and Hemachudha, T. (2002). Rabies reexamined. Lan. Infect. Dis. 2(6): 327-343.

Sami, D., Fihri, F., Schereffer, J.L., Aboulfidaa, N., Wasniewski, M., Zouine, K., Bouslikhane, M., Yahia, K. and Cliquet, F. (2016). Immunogenicity and efficacy of rabivac vaccine for animal rabies control in Morocco. Clin. Exp. Vaccine Res. 5: 60-69.

Sugiyama, M. and Ito, N. (2007). Control of rabies: Epidemiology of rabies in Asia and development of new-generation vaccines for rabies. Comp. Immunol. Microbiol. Infect. Dis. 30: 273-286.

Tepsumethanon, W., Polsuwan, C., Lumlertdaecha, B., Khawplod, P., Hemachuda, T., Chutivangse, S., Wilde, H., Chiewbamrungkiat, M. and Phanuphak, P. (1991). Immune response to rabies vaccine in Thai dogs: A Preliminary Report. Vaccine. 9: 627-630.

Tordo, N. and Poch, O. (1988). Structure of Rabies Virus. In: Rabies, Edt. [Campbell, J.B. and Charlton, K.M.], Boston, pp 25-45.

Van loveren, H., Van amsterdam, J.G.C., Vandebriel, R.J., Kimman, T.G. Rumke, H.C., Steerenberg, P.S. and Vos, J.G. (2001). Vaccine-induced antibody responses as parameters of the influence of endogenous and environmental factors. Environ. Health. Perspect. 109: 757-64.

WHO. (1992). Expert Committee on Rabies. $8^{\text {th }}$ Report. Technical Report Series. 824. Geneva.

WHO (2013). WHO, Expert Consultation on Rabies. Technical Report Series, $2^{\text {nd }}$ report. World Health Organisation, Geneva.

Yale, G.P.I. Ganesan, K.G. Tirumurugaan, S.N., Madhusudana, M., Vijaya, Bharathi, Thangavelu, Ashwin, Yajaman, Belludi, Sampada, Sanyal. and Shaheen, T. (2014). Factors affecting duration of immunity of rabies vaccination in dogs. Vet. Rec. Open. 23: 128-125. 